Vol. 2, No. 2, 2016

УДК: 37.035.4

АМЕРИКАНСЬКА ІДЕНТИЧНІСТЬ : ГЛОБАЛЬНИЙ ВИМІР

\author{
Зазуляк Зоряна \\ Національний університет "Львівська політехніка"
}

(стаття надійшла до редколегї - 7.11.2016 р., прийнята до друку - 13.12.2016 р.)

(c) Зазуляк 3., 2016

Зроблено спробу обтрунтувати міжнародне значення американської ідентичності за допомогою аналізу етнічних, релігійних, політико-правових та економічних параметрів. Визначено, що етнічно сучасну Америку сформульовано на основі асиміляцї̈ корінного населення та переселенців 3 Свропи, Азӥ, Африки тощо. Наголочено на тому, що США притаманна плюралістична релісійна культура. Проаналізовано, щчо політикоправова складова теоретично будується на індивідулізмі, конституціоналізмі та повазі до закону. Економічний аспект американської ідентичності зумовлений розвитком виробництва, корпоративною та індивідуальною конкуренцією, а також системою вільного підприємництва. Подано систематизований огляд механізмів впливу цих складових на сучасне американське суспільство і на міжнародну співпрацю загалом.

Ключові слова: американська ідентичність, США, американці, суспільство, иінності, культура.

\title{
AMERICAN IDENTITY: GLOBAL DIMENSION
}

\section{Zoriana Zazuliak}

The article attempts to analyze the perception of American identity and its international importance through ethnic, religious, political, legal, and economic components. It is determined that ethnically modern America is formed by assimilation of the indigenous population and immigrants from Europe, Asia, Africa, etc. as they contributed to the formation of many political, social, constitutional and religious institutions of the new country, the definition of American identity and values. Along with existing discrimination against indigenous peoples and racism in many areas of American life, the modern United States successfully integrated all immigrants in contemporary American society. It is emphasized that the United States is inherent in a pluralistic religious culture: it takes its roots from the belief that immigrants and servants brought to America. Religious faith, observations and pluralism of religions have become features of American society and an important aspect of social, economic and political life of the USA. The article analyses a political and legal part of the phenomenon as one which is based on individualism, constitutionalism, and respect for law. This approach seeks to unite people around a great version of the American identity, which is rather abstract. The notion of an "American" includes both the materialistic aspects of reality and idealistic and symbolic definition of the term "nation". An economic aspect of the American identity is conditioned by development of production, corporate and individual competition, and free enterprise system. Historically, people have fought for economic and social survival and this competitive nature of American life creates significant disparities of wealth, social inequality, and different life opportunities of people. The impact of these components on contemporary American society and international community is researched.

Key words: American identity, the USA, American people, society, values, culture.

Погляди на американський спосіб життя, країну та народ самих громадян США і осіб, що живуть поза їхніми межами, дуже різняться, а часом і суперечать один одному. Окремі з них основуються на статистичних даних чи фактах, інші зумовлені ідеологією чи стереотипами.

Часто американська ідентичність обов'язково передбачає “винятковість” або “ексепціоналізм” (унікальність місії США в світі, високі прагнення та глобальна відповідальність). Тим не менше існують також внутрішні розбіжності у підходах до визначення власне американських цінностей, інституцій, національної ідентичності, особливостей реалізації внутрішньої та зовнішньої політики [4, с. 48].

Відповідно до багатьох опитувань громадської думки, у американців, як i в інших народів, позитивні почуття та незадоволеність своєю країною чергуються в контексті національних i міжнародних подій. Періоди сумнівів і конфліктів у часи обох світових воєн, Великої Депресії та холодної 
війни, боротьби за громадянські права, воєн у

В'єтнамі, Іраку та Афганістані.

“Глобальний” підхід до зовнішньої політики США був обумовлений подіями в Нью-Йорку і Вашингтоні 11 вересня 2001 р. Зважаючи на загрозу міжнародного тероризму, адміністрація США розпо-

чала захищати свої внутрішньодержавні та світові інтереси, заявила про початок боротьби проти тероризму та ініціювала військові дії в Афганістані й Іраку.

Хоча сьогодні серед американської грома- дськості очевидним $є$ прагнення до більш мирної зовнішньополітичної поведінки США, не слід недооцінювати труднощі процесу прийняття рішень щодо внутрішньодержавних і глобальних проблем. Тому дослідження цієї тематики є важливим з огляду на те, що сьогодні США $є$ ключовим актором міжнародних

відносин, а самоідентифікація кожного американця

впливає не лише на внутрішню, але і на зовнішню політику держави. Крім того, тема сприяє розвитку американознавства в українській політичній думці.

Науковці розглядають проблему американської ідентичності не узагальнено і систематизовано, а враховують “походження" окремих компонент цієї ідентичності - індійську (Дж. Нагел, П. Горс), африканську (Р. Селлерс, С. Ровлі, М. Гехт, Т. Чевус тощо), єврейську (I. Зак, Е. Голдштейн). Власне, систематизований підхід у своєму дослідженні “Американська ідентичність та політика етнічних змін” застосували Дж. Сітрін, Б. Рейнголд і Д. Грін та акцентували на політичних та етнічних аспектах цього явища. Серед вітчизняних дослідників до цього питання грунтовно підійшла $Н$. Бурейко, котра дослідила особливості формування національної ідентичності США та проаналізувала вплив імміграції на неї. Зважаючи на усе вищезгадане, детальнішого дослідження потребує вплив американської ідентичності та їі складових на розвиток зовнішньої політики США, а також розуміння іiі значення для глобальної ролі Америки на міжнародній арені.

Отож основне завдання цієї статті - проаналізувати глобальний вимір американської ідентичності та визначити фактори, що впливали/ють на ії формування.

Для того, щоб зрозуміти сучасну Америку та оцінити, як вона розвивалася історично, необхідно звернути особливу увагу на деякі чинники, що цьому сприяли. Серед них слід назвати:

- відношення до корінних американців та інших етнічних груп (зокрема, афроамериканців);

- ранні колоніальні поселення європейців від кінця п'ятнадцятого століття i формування конкретних соціальних цінностей, релігійних культів та інституційних структур;
- війна за незалежність від Великобританії (1775-1783 pp.);

- розширення нової нації на захід;

- наслідки великомасштабної імміграції в країну, особливо в XIX і XX ст.;

- громадянська війна, що ліквідувала рабство відокремила південні держави від Союзу (1861-1865 pp.);

- принципи нації (людська гідність і права на свободу, справедливість і можливості), що містяться в Декларації про незалежність (1776 р.) і Конституції США (1787 p.);

- ідеології егалітаризму, індивідуалізму та утопізму;

- розвиток корпоративного капіталізму, його управління та бізнесової філософії;

- заохочення державного регулювання та бюрократії, що сприяли обмеженню індивідуальної автономії;

- власне американське ставлення до решти світу, особливо у періоди воєн, холодної війни і на початку ХІХ ст.;

- розвиток США як домінантної економічної, військової та культурної сили з початку ХХ ст.;

- сучасні аргументи щодо того, чи є США ключовим актором сучасної глобалізації (взаємозалежні економічні, політичні та культурні сили) чи щодо того, чи Америка сама піддається глобалізованим силам, що існують поза їі впливами.

Ці історичні події сприяли формуванню чотирьох основних компонентів американської ідентичності, що можуть суперечити один одному й одночасно діяти на рівні ідеалізму та прагматизму:

- першим з них є розмаїта етнічна культура, що основується на розвитку корінної американської цивілізації, європейських колоніальних поселень, афроамериканському рабстві та пізніших хвилях імміграції. Етнічна культура, що іiі зініціювало колоніальне поселення США, основним чином була сформована із переселенців із Британії, що співіснували 3 корінним населенням Америки, а також іншими іммігрантами з Свропи, зокрема Іспанії та Франції. Вони сприяли діяльності багатьох політичних, соціальних, конституційних і релігійних інституцій нової країни, що формували американську ідентичність та цінності, вплив яких відчутний досі. Протягом XIX ст. із північно-західної Європи до США простежувалися значні хвилі імміграції в США. Було також багато іммігрантів з Азії (особливо Китаю) протягом цього часу. У XX ст. більшість переселенців прибували з Південної і Східної Свропи. Цей факт істотно змінив демографічний склад США, оскільки нові іммігранти не були ні 
англійцями, ні протестантами. Наприкінці XX ст. на початку XXI ст. до США емігрувала величезна різноманітність інших національностей 3 усього світу. Іммігранти та переселені африканські раби значно впливали на громадське життя в різні періоди історії США, але водночас вони також стикалися 3 труднощами інтеграції в суспільство через мовні проблеми, соціальний стан чи культурні традиції. Виникали конфлікти і расова напруженість між корінними американцями, афроамериканцями та іммігрантами, які іноді виливалися у насильство [6, с. 71]. Ці чинники виявили нативізм (дискримінація щодо інших корінних народів) та расизм у багатьох сферах американського життя, що часто були навіть узаконені. Загалом можемо стверджувати, що сьогодні США вдалося успішно інтегрувати усіх іммігрантів у сучасне американське суспільство, а новим переселенцям, як правило, вдається адаптуватися до американського життя;

- другим $є$ багатоконфесійна або плюралістична релігійна культура, яка відображає вірування колоністів і іммігрантів та частково існує досі. Вона бере своє коріння із вірувань, які до Америки принесли іммігранти та раби: одні власне привозили і залучали до цих вірувань інших, другі на рідних землях не притримувалися жодних вірувань i асимілювалися. Проте більшість переселенців подорожували до Нового світу заради пригод, нових вражень, аби втекти з Європи, заради матеріальної вигоди та придбання землі. Час від часу неоднорідність релігійної сфери США потребувала місіонерської діяльності. Однак, як правило, релігія i плюралізм конфесій стали визначальними особливостями американського суспільства, порівняно 3 іншими країнами. Незважаючи на те, що питання релігії $є$ особистою справою кожного і $є$ абсолютно окремим від держави, воно є важливим аспектом соціального, економічного та політичного життя суспільства [3, с. 267]. Незважаючи на прагнення залишити релігію поза політикою, питання про те, чи доцільно повністю заперечувати активну роль релігії в суспільному житті США, а також у міжнародних відносинах досі залишається відкритим;

- третьою є політико-правова культура, що теоретично будується на індивідуалізмі, конституціоналізмі та повазі до закону. Цей підхід прагне об'єднати людей навколо ідеальної версії “американськості”, якій притаманні егалітаризм, моральність і патріотизм, що відображені в діяльності політичних і правових інституцій. Необхідність у політико-правовій культурі для підтримки рівноваги і компромісу в суспільстві ілюструє ступінь абстракції у визначенні поняття американської ідентичності
[5, с. 91]. Уявлення про те, чим є “Америка”, необхідно дослідити 3 урахуванням як матеріалістичних аспектів реальності, так і ідеалістичного, абстрактного символу “нації”. Американська політикоправова система враховує маніпуляції групових та ідеологічних інтересів, а також надмірну риторику, спрямовану на просування спільних рішень. Американці знають про масштаби корупції та некомпетентності в політичних і правових системах, а також про те, що ці системи, які de jure орієнтовані на дотримання прав і свобод не завжди такими є в реальності. Американська політична система, що відображає федеральний характер уряду США, частіше перебуває під впливом місцевих і регіональних або державних інтересів, ніж залежить від національної ідеї. Такі факти часто сприяють тому, що американські виборці голосують одночасно за політичних представників різних політичних партій, підтримуючи окремі пункти їхніх програм. Протягом останніх десятиліть в академічних колах говорять про апатію та низький рівень участі американських громадян у політичному житті країни. Вони також розрізняються за своїми методами вимірювання явки виборців на виборах [4, с. 64]. Низька явка і реєстрація громадян на виборах передбачає відчуження від політичного процесу та акцентує на тому, що владу обирає меншість - яскравим прикладом є вибори, на яких переміг Дональд Трамп. I безпосередньо такий вибір американців викликав неймовірний резонанс на міжнародній арені та дискусії 3 приводу того, наскільки радикально зміниться зовнішньополітичний вектор США;

- четвертий напрям представлений економічною та споживчою культурою, що зумовлені корпоративною та індивідуальною конкуренцією, а також розвитком виробництва, що стимулює прибуток та споживання товарів і послуг. Американці зазвичай вірять в індивідуалізм і систему вільного підприємництва, яка передбачає поставку товарів і послуг, затребуваних на споживчому ринку. Історично, люди боролися за економічне і соціальне виживання: процес, який може призвести до експлуатації інших і “виживання найсильнішого” відповідно до підходу Дарвіна. Конкурентність американського життя створює значні диспропорції багатства, породжує соціальну нерівність та різні життєві можливості людей. Американці звикли скептично ставитися до "Великого бізнесу" та "Великого уряду" [2]. Проте, дебати 3 приводу неефективності капіталістичної моделі часто ігнорують значну економічну співпрацю, діяльність благодійних організацій та волонтерство в американському суспільстві. 
Формування американського суспільства було лише опосередковано зумовлене цими чинниками, адже молодь, політичні активісти, радикали та представники інтелігенції загалом не перебували під їхніми впливами. Внутрішні конфлікти американського суспільства на цьому рівні відбувалися протягом усієї історії США і підривали ідеали національної гармонії та єдності.

Від моменту здобуття незалежності в 1776 році у США поступово формувалася унікальна американська культура, що основується на ідеї національної ідентичності та притаманна більшості американців. Складність полягає у визначенні того, із чого ця американська культура насправді складається на практиці. Деякі дослідники стверджують, що нація останнім часом відходить від своїх традиційних основ, переживає кризу самоідентичності та дещо втрачає напрямок розвитку. Інші ж стверджують, що відповідно до перепису 2000 р. передбачається, що американський націоналізм та американська єдність насправді набувають усе більшого сенсу.

Названі чотири важливі аспекти американської ідентичності впливають на різні сфери американського суспільства - зокрема, на освіту, соціальну сферу, засоби масової інформації, мистецтво, спорт і відпочинок. Вони також частково відповідають на питання “Що означає бути американцем?” і дають визначення національній ідентичності.

Історичною дилемою для США було збалансування потреби громадянської єдності поряд із реальністю етнічного різноманіття і таким чином уникнути небезпеки фрагментації. Спочатку акцент робився на “американізаціі” або асиміляції різних етнічних груп на англо-американській основі. Цей процес поступово починає розглядатися як підвищений тиск на іммігрантів, що змушені асимілюватися у американізовану домінуючу культуру із поступовою втратою етнічної ідентичності.

Протягом останніх десятиліть, дебати про національну ідентичність зосереджувалися на питаннях єдності на противагу різноманітності (етнічного плюралізму). Ці протилежні погляди відображають аргументи суперечок між лібералами та консерваторами. Зокрема, ліберальна політика i програми позитивних дій, спрямовані на підтримку меншин у США, зокрема у сфері освіти та працевлаштування. Консерватори визнають традиційні американські цінності, а також виступають проти ліберальної політики щодо абортів, контролю за вогнепальною зброєю, одностатевих шлюбів, релігії, питання смертної кари та імміграції [1, с. 28]. Ці дебати 3 приводу фундаментальних американських цінностей призводять до ще більших суперечностей щодо національної ідентичності та сприяють розгляду США як “мозаїки” етнічно, культурно й ідеологічно. Це може призвести до гібридної культурної самобутності 3 одного боку, чи до посилення національних зв'язків - 3 іншого боку.

До певної міри, американський ідеал $є$ абстрактним поняттям, що не відображає дійсності і якого неможливо практично досягти. 3 іншого боку, акценти на етнічних відмінностях послаблюють можливість досягнення цінностей, які могли б представляти своєрідний “американський спосіб життя”. Деякі дослідники вважають, що перед американським суспільством виникає загроза з боку інших культур і груп інтересів, а також наголошують на тому, що ці конфлікти послабили почуття всезагальної американської ідентичності.

Історично американці намагалися сформулювати загальнонаціональну ідентичність та інституційну єдність через об'єднання різних етнічних груп навколо ідеї американської ідентичності через такі важливі елементи, як Національний прапор, Декларація про незалежність, Національний гімн, особистість Авраама Лінкольна, Конституцію. Вони сприяють сприйняттю громадян ідеальних уявлень про те, що таке американське громадянство, Америка i американська ідентичність. 3 цими символами також традиційно пов'язані певні значення, зокрема, ті права, що випливають 3 Декларації про незалежність, Конституції, Біллю про права.

У всіх спробах визначити американську ідентичність наголошується на таких елементах, як самостійність, індивідуалізм, незалежність, утопізм, свобода, егалітаризм, демократія, популізм і повага до закону. Вони випливають з ідей пуританської релігії і європейського Просвітництва, що пов'язані із Декларацією про незалежність і Конституцією США. Так, у американському суспільстві існують ідеалізм і абстракція, що співіснують, i навіть часто конфліктують, 3 реальністю. Проте, ця ситуація не унікальна: вона перегукується із досвідом інших країн, особливо федерацій чи держав, у яких проживають народи 3 відмінними традиціями, яким необхідно формулювати нову національну ідентичність, зберігаючи деякі аспекти свого походження [7, с. 85].

Ступінь пропагування американських цінностей у суспільстві США $є$ значним, як на особистісному, так і на національному рівні. Ключовою особливістю американського життя $є$ те, як кожен окремий індивід може комбінувати традиційні ідеали нації з фактичними реаліями суспільства і справлятися $з$ результатами таких комбінацій.

Існує також підхід, що пояснює американську ідентичність особливими “американськими рисами”. 
Такі характеристики, як неспокій, зміни, дії, мо- більність, новий досвід, самовдосконалення і віра впотенціал є типово американською поведінкою. Американці відмовляються “плисти за течією” чи вести осілий спосіб життя і натомість шукають нові робочі місця, нові горизонти і нові починання задля самореалізації та самовизначення.

3 іншого боку, багато американців шукають стабільності в житті, у державних інституціях та національній ідентичності. Тобто, поряд із нефор- мальністю американського життя, що основуються на індивідуалізмі, егалітаризмі та історичній відмові від європейських звичок, багато американців поважають формалізованість, ієрархію, порядок та відпо- відальність. Американці підкреслюють свою індиві- дуальність та бажання бути вільними, але спільність, благодійні організації та робота у команді також є характерними ознаками американського життя.

Отже, ніхто не може визначити єдиного набору ознак, які спільні для всіх американців. А акцентування на різності, індивідуальних відмін- ностях швидше призводять до суперечностей, аніж єдиних переконань. Американські риси є універсаль- ними, які характерні і для інших суспільств та не є ні винятковими, ні притаманними лише американцям.

Проте чотири основні параметри, що окреслені у цій статті та співіснування різних субкультур сприяли формуванню американської ідентичності та іміджу США, що визнані на міжнародному рівні та впливають на розвиток глобальної культури, як спрощено і стереотипно, так і у масштабніших проявах. Американська ідентичність проявляється у голлівудських фільмах, телебаченні та радіо, музиці та мистецтві, газетах і журналах, спорті, способі життя, брендах і магазинах, корпоративних і фінан- сових інституціях, бізнесфілософії, політичній діяльності, етнічних проблемах та масовій культурі.

Тематика, що стосується питання існування чи не існування американської ідентичності, американськості та іiі впливу на світ та міжнародні відносини є завжди актуальною та потребує подаль- ших наукових розвідок. Зокрема, детальнішого розгляду потребують чинники, що впливають на формування американської ідентичності, а також питання виняткової ролі (ексепціоналізму) Сполу- чених Штатів на міжнародній арені.

1. Alba R. Remaking the American Mainstream: assimilation and contemporary immigration / R. Alba, V. Nee. Cambridge, Harvard: Harvard University Press, 2003. - 384 p. 2. Bloom A. The Closing of the American Mind/A. Bloom. - New York: Touchstone, 1988. - 392 p. 3. Campbell N. American Cultural Studies: an introduction to American culture / N. Campbell, A. Kean.-London : Routledge, 2012. - 352 p. 4. Hall J. A. Is America Breaking Apart? /J. A. Hall,

C. Lindholm. - Princeton, NJ : Princeton University Press, 2001. - 184 p. 5. Huntington S. Who Are We? America's great debate /

S. P. Huntington. - New York: Simon \& Schuster, 2004. - 428 p. 6. Jenkins P. A History of the United States /

P. Jenkins. - London: Macmillan-Palgrave, 2003. -368 p.

7. Stevenson D. K. American life and Institutions / Douglas K. Stevenson. - Klett, 1996. - 176 p. 